\title{
Dwarf mice produced by genetic ablation of growth hormone-expressing cells
}

\author{
Richard R. Behringer, ${ }^{1}$ Lawrence S. Mathews, ${ }^{2}$ Richard D. Palmiter, ${ }^{2}$ and Ralph L. Brinster ${ }^{1}$ \\ ${ }^{1}$ Laboratory of Reproductive Physiology, School of Veterinary Medicine, University of Pennsylvania, Philadelphia, \\ Pennsylvania 19104 USA; $^{2}$ Department of Biochemistry and Howard Hughes Medical Institute, University of Washington \\ Seattle, Washington 98195 USA
}

\begin{abstract}
Fusion of the 310 bp located 5' of the rat growth hormone (GH) gene to the human GH structural gene resulted in somatotrope-specific expression in transgenic mice. Human GH transcripts were detected only in pituitaries of these mice, and immunocytochemical analyses revealed that this expression was limited to GH-expressing cell types. The rat GH 5' sequences were then used to direct the expression of diphtheria toxin to the GHexpressing cells of transgenic mice. A line of mice was established which lacks detectable levels of circulating GH. This deficiency resulted in dwarfism; transgenic animals grew only to half the size of nontransgenic littermates. Nearly all somatotropes were absent, as shown by GH immunostaining in the transgenic pituitaries. Prolactin (PRL)-producing lactotropes, thought to share a common cellular origin with somatotropes, were also reduced in numbers. A model for the lineal relationships between GH- and PRLsynthesizing cells is proposed.
\end{abstract}

[Key Words: Tissue-specific expression; cell lineage analysis]

Received January 13, 1988; revised version accepted March 15, 1988.

The diverse cell lineages of multicellular organisms are generated from a hierarchy of stem cells. Determining the relationships between cell lineages and stem cells creates a framework for the detailed studies of complex developmental systems (Nishida and Satoh 1983, 1985; Sulston et al. 1983; Cameron et al. 1987; Dale and Slack 1987; Lawson and Pederson 1987; Technau 1987). Several approaches have been used to study cell lineage relationships during development; however, in very complex organisms not all lineages are amenable to manipulation (Technau 1987). Recently we developed a transgenic methodology that permits deletion of a specific cell type during the development of an organism by expression of a toxic gene product under the control of an enhancer/promoter from a gene expressed in only one cell type. In our first example we chose the enhancer/ promoter from the rat elastase I gene which is only expressed in differentiated pancreatic acinar cells; expression of an elastase-diphtheria toxin fusion gene in that cell type resulted in transgenic mice lacking an exocrine pancreas (Palmiter et al. 1987). If one chose an enhancer/promoter from a gene that is expressed in a stem cell of two or more differentiated cell types, then one would predict that all the descendants of that stem cell should be eliminated. In this paper we assessed the feasibility of this prediction.

The diphtheria toxin A chain (DT-A) gene that was used for these experiments was engineered so that the protein product would be retained within the cytoplasm where it could enzymatically ADP-ribosylate elongation factor 2, and thereby inhibit protein synthesis (Maxwell et al. 1986; Palmiter et al. 1987). The DT-A chain cannot gain access to the cytoplasm of intact cells in the absence of the B-chain; thus, any DT-A that might be liberated from dying cells should not affect neighboring cells.

The anterior pituitary gland (or adenohypophysis) develops from an ectodermal bud that protrudes from the roof of the oral cavity and becomes juxtaposed to a neuroectodermal extension from the base of the brain, the posterior pituitary (or neurohypophysis). A variety of endocrine cells develop within the anterior pituitary that specialize in the synthesis and secretion of polypeptide hormones such as growth hormone $(\mathrm{GH})$, prolactin (PRL), gonadotropins (FSH and $\mathrm{LH})$, corticotropin (ACTH), and thyrotropin (TSH). The precise lineal relationships among all of these endocrine cells is not established. However, several observations suggest that GHsynthesizing (somatotropes) and PRL-synthesizing cells (lactotropes) may be derived from a common precursor that synthesizes both gene products (Hoeffler et al. 1985). Although somatotrope and lactotrope cells can be distinguished morphologically, hemolytic plaque assays and immunocytochemical analysis reveal that cells positive for both gene products can be detected in the pituitary of immature and adult rodents (Frawley et al. 1985; Hoeffler et al. 1985). Furthermore, cell lines that continue to express both of these hormones have been established from pituitary tumors (Bancroft 1981). Because the GH and PRL genes have been isolated and their regulatory elements defined in considerable detail by gene transfer, DNA-protein binding, and cell-free transcription experiments (Nelson et al. 1986; Bodner and Karin 
1987; Lefevre et al. 1987; West et al. 1987), this system seemed well-suited for cell ablation analysis. It is particularly favorable because these cell types are not essential for survival of the embryo; thus, we anticipated that if cell-specific expression could be achieved, then mice would develop and survive to adults. We predicted that if both GH and PRL are synthesized in the stem cell, then expression of a diphtheria toxin gene under the control of a GH enhancer/promoter should eliminate not only somatotrope cells from the anterior pituitary but lactotrope cells as well.

\section{Results}

\section{Somatotrope-specific expression}

To determine whether the rat growth hormone $(\mathrm{rGH})$ sequences identified by cell transfection, DNase footprinting, and in vitro transcription were sufficient for proper GH cell-specific expression in vivo, we constructed a fusion gene containing $310 \mathrm{bp}$ of $\mathrm{rGH} 5^{\prime}$ flanking sequences fused to the human growth hormone (hGH) structural gene (Fig. 1). In a control experiment, the hGH gene together with additional hGH 5'-flanking DNA (upstream to $-83 \mathrm{bp}$, which includes the promoter but deletes the enhancer) was used to produce eight transgenic mice. Human GH mRNA was not detectable in pituitary, liver, kidney, brain, or gonads in any of the eight animals. Thus, the hGH sequences in the $\mathrm{rGH}-\mathrm{hGH}$ construct can be used as a reporter for DNA, mRNA, and protein analyses because they alone do not activate transcription in transgenic mice.

The $\mathrm{rGH}-\mathrm{hGH}$ gene was microinjected into fertilized mouse eggs resulting in 14 founding transgenic animals that grew normally. Expression of hGH was monitored in various tissues (liver, pancreas, brain, spleen, heart, kidney, and pituitary) from eight of these founders by a solution hybridization assay for mRNA and/or immunostaining for hGH protein, and in each animal expression was detected only in the pituitary (Table 1). The steadystate levels of pituitary hGH transcripts observed in four of these animals ranged from 3400 to 9300 molecules/ cell. Immunocytochemical analysis of the pituitaries from the other four founders showed that hGH-specific staining was limited to cells that expressed mouse GH (Fig. 2). A population of hGH-staining cells also stained positively for PRL, suggesting that these are cells termed mammo-somatotropes because they produce both $\mathrm{GH}$ and PRL (Frawley et al. 1985). To determine if mice normally possess mammo-somatotropes, control pituitary sections were stained simultaneously for endogenous $\mathrm{mGH}$ and mPRL. Mammo-somatotropes were readily observed (not shown). Five hundred pituitary cells were scored for GH, PRL, and GH plus PRL. Approximately equal proportions of each of the three cell types were observed, similar to those values determined for adult male rat pituitary cells (Frawley et al. 1985). Thus, the sequence information encoded within the 310-bp fragment from the $5^{\prime}$ region of the $\mathrm{rGH}$ gene was sufficient to direct expression to $\mathrm{GH}$-expressing cells in transgenic mice.

This same rGH-hGH construct was also coinjected into fertilized mouse eggs with a chimeric gene in which the mouse metallothionein-I (MT) promoter/regulatory region was fused to a human growth hormone-releasing factor (hGRF) minigene (Hammer et al. 1985). Transgenic mice harboring MT-hGRF transgenes exhibit pituitary hyperplasia and enhanced growth rates due to the stimulation of endogenous GH expression and release from the pituitary (Hammer et al. 1985). We hypothesized that the coinjection and expression of the MT-hGRF transgene would stimulate the expression of the $\mathrm{rGH}-\mathrm{hGH}$ transgene. Three founding transgenic mice were produced that carried both gene constructs. Two of these mice expressed hGH transcripts in the pituitary and the pituitaries were enlarged (Table 1).

\section{Generation of dwarf mice}

To direct expression of diphtheria toxin to somatotropes, we inserted DT-A into the first exon of $\mathrm{rGH}_{-}$

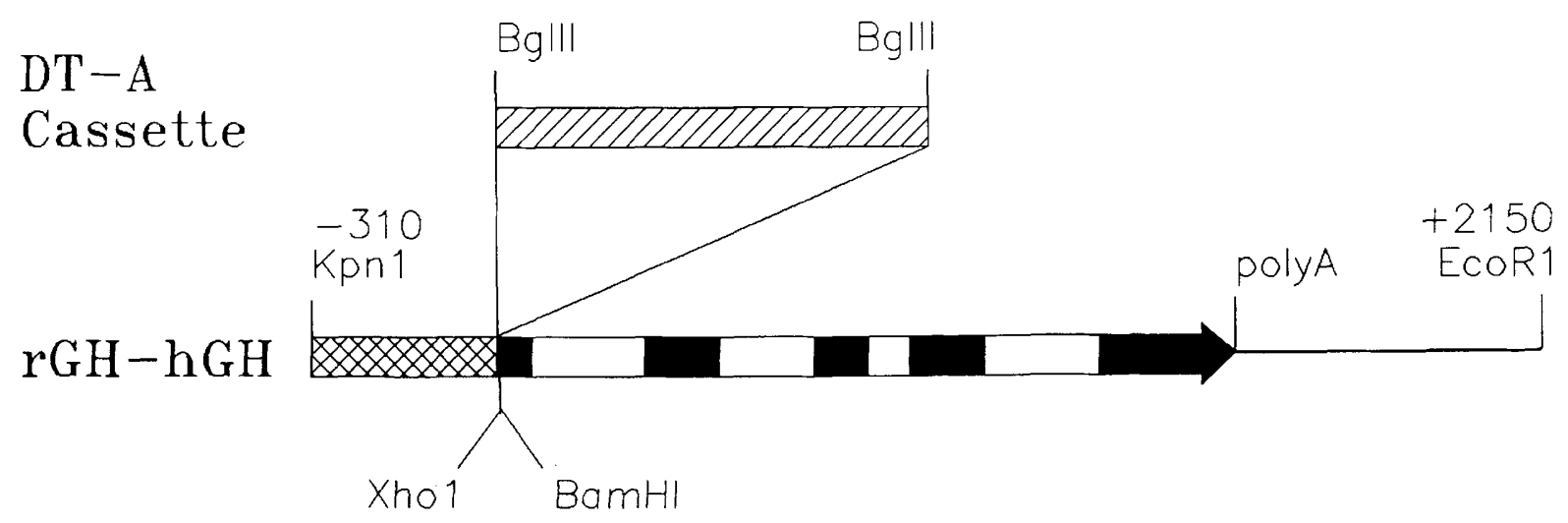

Figure 1. Diagram of $\mathrm{rGH}-\mathrm{hGH}$ gene and DT-A cassette. For the rGH-DT-A construct, the DT-A cassette was inserted into the first exon of the hGH gene such that the first open reading frame in the mRNA would be that of DT-A. (Cross hatch) rGH sequence; (solid) hGH exons; (open) hGH introns. 
Table 1. hGH expression in $r G H-h G H$ and $r G H-h G H+M T h G R F$ transgenic mice

\begin{tabular}{|c|c|c|c|c|}
\hline Construct & $\begin{array}{l}\text { Mouse \# } \\
\text { and sex }\end{array}$ & $\begin{array}{l}\text { Body } \\
\text { weight }|g|^{a}\end{array}$ & $\begin{array}{l}\text { Pituitary } \\
\text { size }^{b}\end{array}$ & $\begin{array}{l}\text { hGH expression } \\
\text { (molecules/cell) }\end{array}$ \\
\hline $\mathrm{rGH}-\mathrm{hGH}$ & $\begin{array}{l}422-3 \mathrm{M} \\
423-1 \mathrm{~F} \\
423-7 \mathrm{~F} \\
424-8 \mathrm{~F}\end{array}$ & $\begin{array}{l}23.4 \\
22.0 \\
20.8 \\
17.4\end{array}$ & $\begin{array}{l}+ \\
+ \\
+ \\
+\end{array}$ & $\begin{array}{l}3,420 \\
7,870 \\
9,270 \\
5,750\end{array}$ \\
\hline $\mathrm{rGH}-\mathrm{hGH}+\mathrm{MT}-\mathrm{hGRF}$ & $\begin{array}{l}1781-1 \mathrm{~F} \\
1781-4 \mathrm{M} \\
1781-6 \mathrm{~F}\end{array}$ & $\begin{array}{l}19.1 \\
32.7 \\
18.9\end{array}$ & $\begin{array}{c}+ \\
++ \\
++\end{array}$ & $\begin{array}{r}0 \\
9,500 \\
34,500\end{array}$ \\
\hline
\end{tabular}

a Weights at $6-7$ weeks of age. Normal weight range for this age: male $22.8 \pm 2.2$; female $19.5 \pm 1.5$.

b Relative size compared with normal $|+|$ controls.

${ }^{\mathrm{c}}$ hGH mRNA values were determined by solution hybridization with ${ }^{32} \mathrm{P}$-labeled oligonucleotides specific for hGH mRNA using single-stranded Ml3 carrying the coding strand of hGH as a standard. The average DNA content of a normal pituitary was $5 \mu \mathrm{g}$; RNA content was $20 \mu \mathrm{g}$.

hGH in a manner similar to that used successfully with an elastase-hGH gene construct (Palmiter et al. 1987) (Fig. 1). The rGH-DT-A and MT-hGRF genes were coinjected into the pronuclei of fertilized mouse eggs. Twenty of the 66 pups generated carried one or both gene constructs. Six carried rGH-DT-A alone, one MThGRF alone, and thirteen harbored both transgenes. At approximately 10 days after birth, 2 of the 66 animals generated were obviously smaller than their littermates. These two were transgenic and harbored both transgenes. By 7 weeks of age the two smaller pups were onethird to one-half the size of their normal-sized litter- mates (Fig. 3). One of these two animals died, the other, male 1982-2, was bred to a superovulated weanling female and the resulting fertilized eggs transferred to a pseudopregnant foster mother. By this method a line of mice was established in which rGH-DT-A and MThGRF) cosegregated with the dwarf phenotype. None of the other founding animals in this experiment exhibited an impairment in growth. In a second experiment, two additional transgenic mice carrying both gene constructs were generated. One animal, female 159-7, had impaired growth, the other grew to normal size. A line of mice could not be established from this dwarf female.
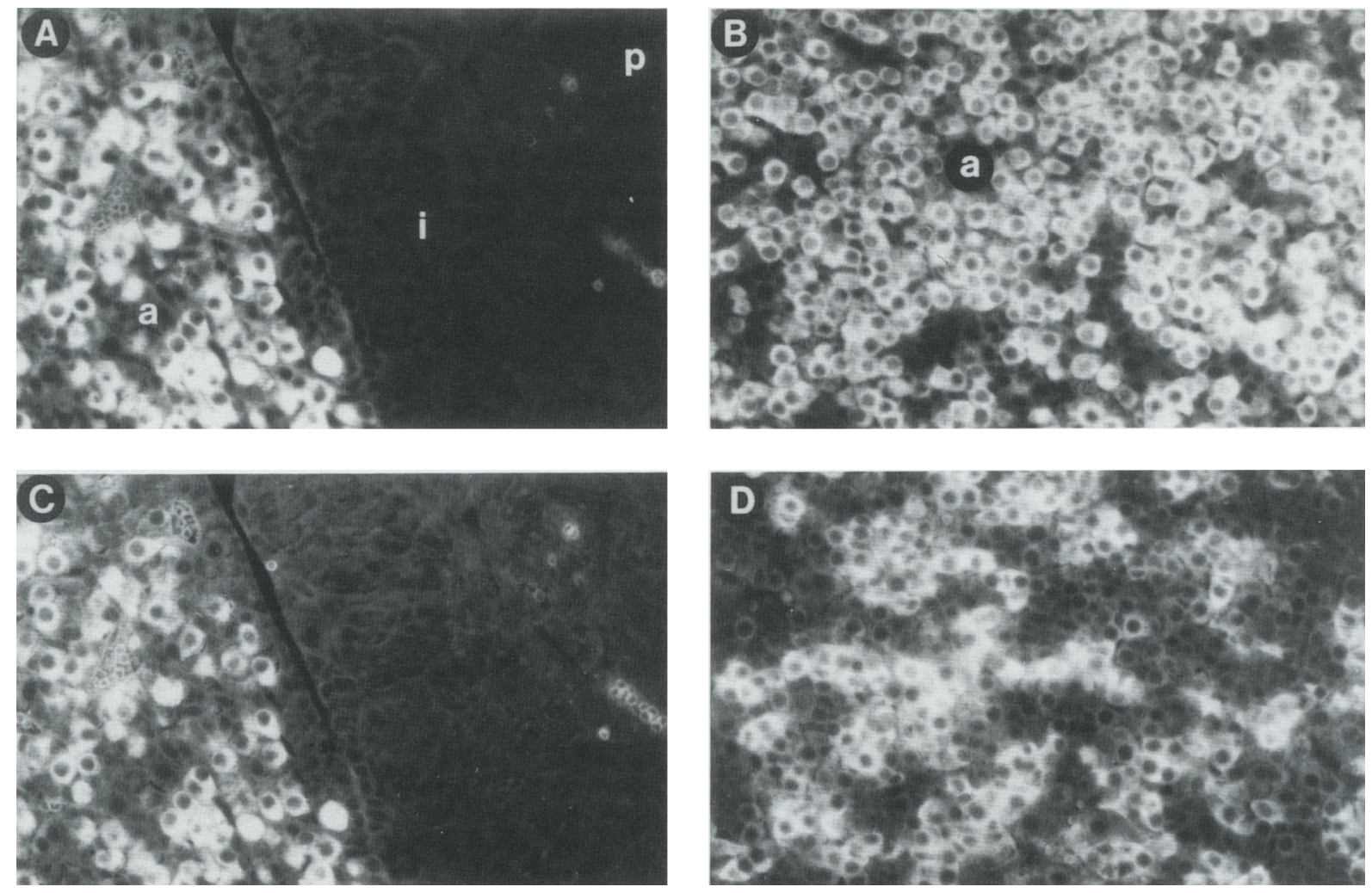

Figure 2. Dual Indirect immunofluorescence of pituitaries from female rGH-hGH transgenic mouse 426-3. $(A)$ Anti-hGH; $(B)$ anti-hGH; $(C)$ anti-rGH; $(D)$ anti-PRL. $A$ and $C$ are the same section; $B$ and $D$ are the same section. (a) Anterior; (i) intermediate; (p) posterior pituitary. 
Behringer et al.

Figure 3. rGH-DT-A transgenic mice. Founder 1982-2 (left) and nonexpressing transgenic littermate (right), at 2 months of age.

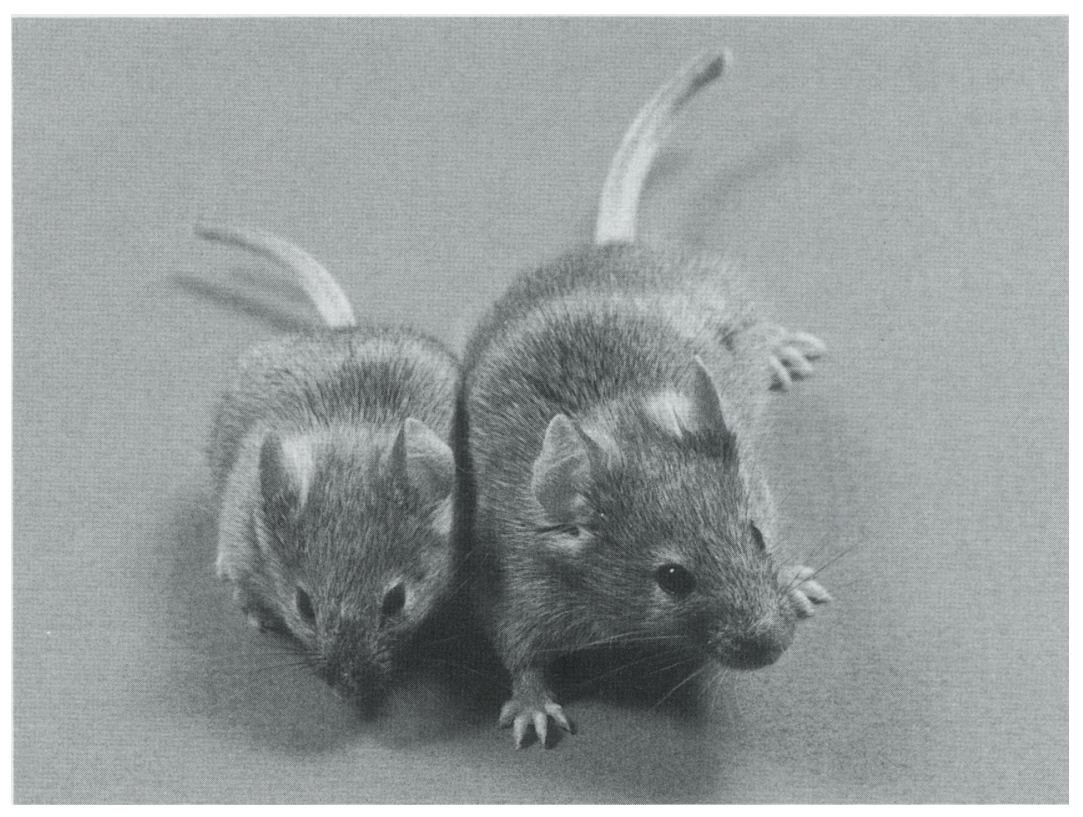

The 1982-2 males have not successfully bred with normal adult females and transgenic females have not produced progeny when housed with transgenic or normal males. Therefore, we have maintained this line in the manner described above or by in vitro fertilization. Subfertility has also been observed in another dwarf mouse mutant, little (Chubb 1987). In addition to this reproductive difficulty, adult animals from the 1982-2 line exhibit a progressive lack of coordination and contracture of the front paws. We do not know if these problems are a consequence of $\mathrm{rGH}-\mathrm{DT}$-A expression in other cell types, a secondary consequence of $\mathrm{GH}$ deficiency, or the result of a dominant insertional mutation.

We compared the growth of mice from the 1982-2 line with controls (Fig. 4). The pattern of growth observed is consistent with data on the role of $\mathrm{GH}$ during early postnatal growth. Both $\mathrm{GH}$-deficient mice and hypophysectomized rats grow at approximately normal rates for 2 weeks after birth (Walker et al. 1950; Eicher and Beamer 1976). In addition, transgenic mice harboring foreign GH genes expressing high levels of $\mathrm{GH}$ do not show accelerated growth rates until 3 weeks after birth (Palmiter et al. 1982, 1983; Hammer et al. 1984).

Serum GH from mice of of the 1982-2 line was measured by radioimmunoassay. Immunoreactive $\mathrm{GH}$ was undetectable $(\leqslant 0.78 \mathrm{ng} / \mathrm{ml}$ ) in transgenic animals (Table 2). In addition, GH was also undetectable by SDS-PAGE analysis of pituitary proteins (data not shown), supporting the interpretation that GH-synthesizing cells were absent. Since many of the physiological actions of GH are believed to be mediated through insulin-like growth factor I (IGF-I) (Van Wyk 1984), plasma IGF-I levels were also assayed. IGF-I levels were detectable in the 1982-2 line but were reduced approximately eightfold in comparison to controls (Table 2), consistent with data on the GH dependence of IGF-I expression in other GH-deficient mice and hypophysectomized rats ( $\mathrm{D}^{\prime} \mathrm{Er}$ cole et al. 1984; Mathews et al. 1986; Roberts et al. 1986). The MT-hGRF construct had been coinjected along with the rGH-DT-A gene to stimulate the expression of the toxin gene. Various tissues from mice from line 1982-2 were analyzed for hGRF mRNA by solution

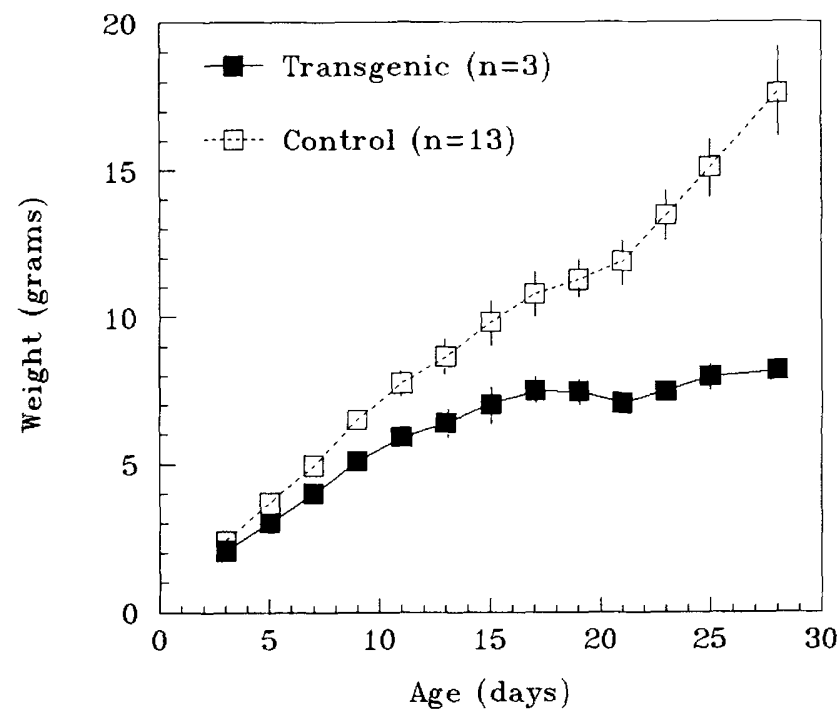

Figure 4. Weight gain of $\mathrm{rGH}-\mathrm{DT}$-A transgenic mice from the 1982-2 line. Transgenic pup weights are significantly different from control littermate weights as early as 5 days of age. The dwarf mice cease growth at approximately 6 weeks of age, maintaining a weight of from 10 to 15 grams. Standard error bars are as indicated. Those markers lacking error bars have a standard error value equal to or less than the size of the marker.

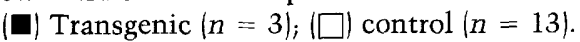


Table 2. Circulating hormone levels in $r G H-D T-A$ transgenic mice

\begin{tabular}{lcr}
\hline & $\mathrm{GH}(\mathrm{ng} / \mathrm{ml})^{\mathrm{a}}$ & \multicolumn{1}{c}{ IGF-I $(\mathrm{ng} / \mathrm{ml})^{\mathrm{b}}$} \\
\hline Transgenic & $0(0 / 4)$ & $42.2 \pm 9.6(n=3)$ \\
Control & $36 \pm 14(4 / 7)$ & $352.6 \pm 10.3(n=3)$ \\
\hline
\end{tabular}

Animals were analyzed at $9-10$ weeks of age.

a $\mathrm{GH}$ level of detection was $0.78 \mathrm{ng} / \mathrm{ml}$. The fraction of mice with detectable levels of GH is shown in parentheses. It is not surprising that some wild-type mice would have undetectable $\mathrm{GH}$, since circulating $\mathrm{GH}$ values undergo temporal fluctuations (Eden 1979).

${ }^{b}$ Mean values \pm standard deviation. Nanogram equivalents of human IGF-I per milliliter of plasma.

hybridization. While hGRF transcripts were present (data not shown), plasma hGRF levels were indistinguishable from control values $\{\leqslant 3.7 \mathrm{ng} / \mathrm{ml}\}$. Thus, the usefulness of the coinjected MT-hGRF construct in this approach is unknown.

\section{Immunocytochemical analysis}

The pituitaries from mice of the 1982-2 line were approximately one-fourth the size of normal controls. Histological examination showed that the intermediate and posterior lobes were apparently unaffected by transgene expression. Furthermore, the organization of cells in the anterior lobe into chords and clusters was maintained. In normal pituitaries, somatotropes and lactotropes are recognized as granule-filled acidophilic cells. In transgenic pituitaries there was a marked decrease in the numbers of these cell types (Fig. 5B).

To identify potential GH-expressing cells in the pituitaries of rGH-DT-A transgenic mice, GH was localized by immunocytochemistry. GH-synthesizing cells were virtually nonexistent in pituitaries from 1982-2 $\mathrm{rGH}-$ DT-A mice; however, rare intensely staining GH positive cells were observed either singly or in clusters of two to eight cells (Figs. 5A and 6A,C). GH immunostaining of serial sections of pituitaries from $5 \mathrm{rGH}-$ DT-A mice revealed that there were on average approximately $10 \mathrm{GH}$-staining cells present per pituitary (Fig. $6 \mathrm{E})$. Since, there are about $20-25 \times 10^{4}$ growth hormone cells in the adult mouse pituitary gland /Sasaki and Sano 1982 |, about $0.01 \%$ of the GH-cells may escape DT-A-mediated destruction.

These same pituitaries were screened simultaneously for the presence of lactotropes by PRL immunostaining. PRL-synthesizing cells were also reduced in numbers, although the extent of that reduction was not as great as for $\mathrm{GH}$ cells (Figs. 5F and 6B,D,F). Curiously, female 159-7, demonstrated normal PRL staining, while a pattern of GH staining similar to that of the 1982-2 line was observed (data not shown).
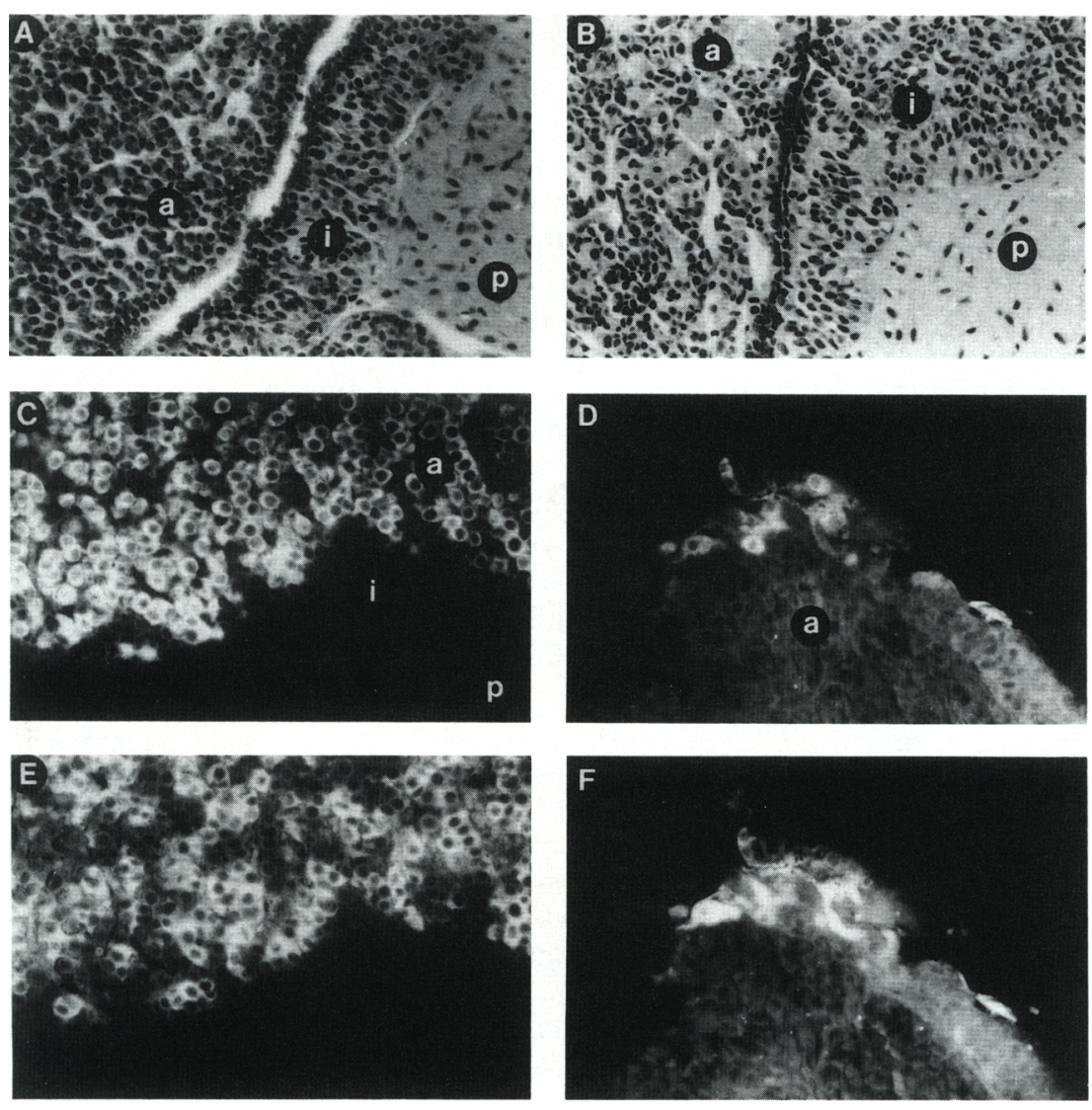

Figure 5. Expression of $\mathrm{GH}$ and PRL in pituitaries from rGH-DT-A transgenic mice. $(A, C, E)$ control; $(B, D, F)$ transgenic. $(A, B) \mathrm{He}$ matoxylin and eosin-stained sections. Immunocytochemical localization: anti-rGH $(C, D)$; anti-mPRL $(E, F) . C$ and $E$ are the same section; $D$ and $F$ are the same section. (a) Anterior; (i) intermediate; (p) posterior pituitary. Magnification, $400 \times$. 

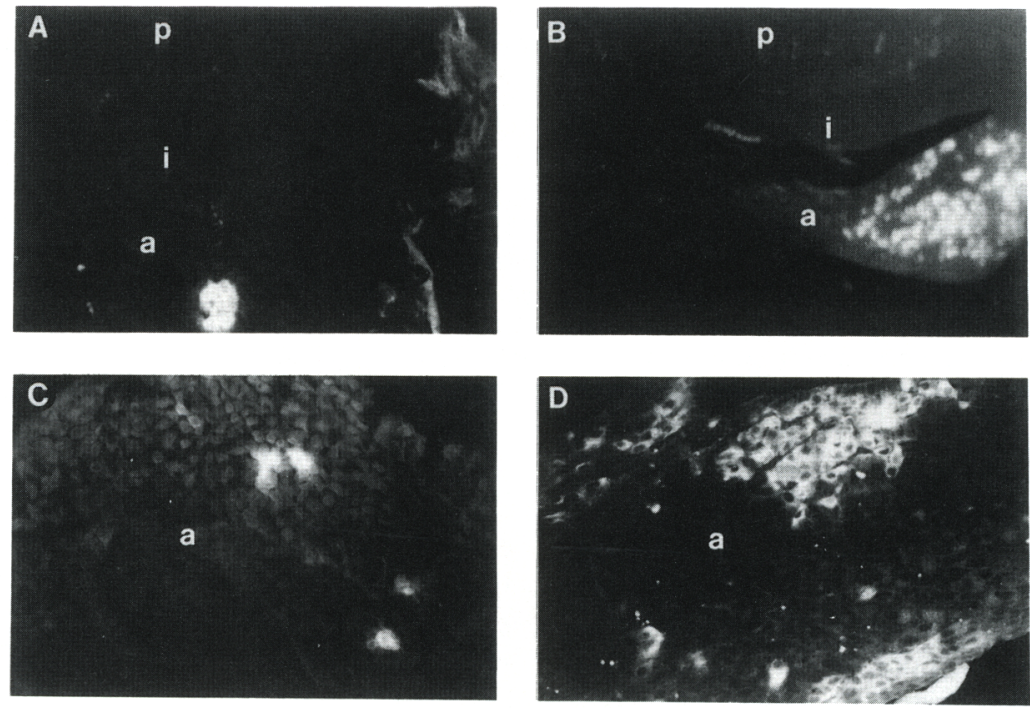

Figure 6. Quantitation of GH and PRL pituitary cells in rGH-DT-A transgenic mice. $(A, C)$ Representative pituitary sections stained with anti-rGH; $(B, D)$ representative pituitary sections stained with anti-PRL. (a) Anterior; (i) intermediate; (p) posterior pituitary. (E) Quantitation of $\mathrm{GH}+$ cells; $\{\mathbf{F}\}$ quantitation of PRL + cells in tissue sections compiled from a group of five rGH-DT-A pituitaries showing that lactotropes are in greater abundance than somatotropes.
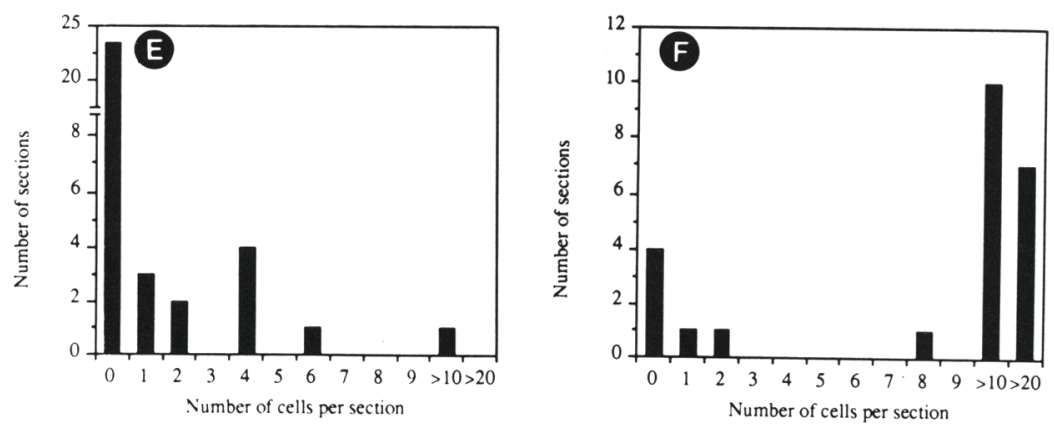

\section{Discussion}

We have shown that the 310 -bp sequence flanking the rGH gene is sufficient to direct expression of the hGH structural gene to the pituitary. Human GH mRNA was found only in the pituitary, and immunocytochemistry revealed that it was expressed only in cells that synthesize mouse growth hormone (somatotropes and mammosomatotropes). All of the transgenic mice expressing the $\mathrm{rGH}-\mathrm{hGH}$ fusion gene exhibited normal growth. Because $\mathrm{GH}$ genes are normally under complex negative feedback control, it may not be possible to exceed the normal endogenous level of GH mRNA by introducing exogenous GH genes driven by GH enhancer/promoters. These results suggest that these genes are not only expressed but are regulated properly and they also confirm the conclusions derived by transfection of $\mathrm{rGH}$ or hGH genes into various tissue culture cell lines (Nelson et al. 1986; Lefevre et al. 1987). Lefevre et al. (1987) and Bodner and Karin (1987) have identified two related cisacting elements that bind a pituitary-specific transcription factor. Furthermore this factor activates transcription of the hGH gene when it is added to a heterologous nuclear extract. These cis-acting elements are centered at about -80 and -120 in the hGH promoter region; similar sequences are found in comparable locations in the rGH promoter (Barta et al. 1981; West et al. 1987). Although there are binding sites for other proteins in the promoter region as well, the available data suggest that the protein that binds to these two elements may be the critical determinant for cell-specific expression of the $\mathrm{GH}$ gene. We have also produced four transgenic mice carrying the bovine GH 5'-flanking region fused to SV40 $\mathrm{T}$ antigen; all of these mice developed pituitary tumors, providing additional support for the conclusion that all of the sequences required for pituitary expression lie 5' of the transcription start site (unpubl.).

Further support for the cell specificity of the rGH enhancer/promoter region comes from the experiments in which this sequence was fused to DT-A. If this gene were expressed in any essential cell type during development, we would have anticipated embryonic or neonatal lethality. Previously, we showed that expression of DT-A in pancreatic acinar cells leads to neonatal death (Palmiter et al. 1987). However, there was no evidence of morbidity with the rGH-DT-A construct and the number of transgenic mice born was in the normal range. Only 3 of $21(14 \%)$ transgenic mice carrying the rGH-DT-A gene had impaired growth indicative of appropriate expression. In contrast, pituitary expression was detected in all of the mice (8/8) harboring the rGHhGH gene. We noted a similar inhibition of expression when the 795-bp DT-A cassette was inserted into the elastase-hGH gene, suggesting that sequences within the DT-A cassette interfere with the transcriptional ac- 
tivation of the transgene in most chromosomal locations (Palmiter et al. 1987). Perhaps by enlarging exon 1 of the hGH gene we have inappropriately displaced sequences lying $3^{\prime}$ that normally contribute to transcriptional activation. We have suggested previously, that the introns of the rGH gene are important for efficient transcription (Brinster et al. 1988).

We have been able to establish a line of mice that appear to be normal in most respects except for their diminuitive size, reproductive difficulties, and neurological symptoms. Ablation of the GH-expressing cell types during development resulted in the birth of normal pups, suggesting that $\mathrm{GH}$ is not required during embryogenesis. The 1982-2 line of dwarf mice provides another GH-deficient animal model. Dwarf strains of mice have been described previously (Snell 1929; Schaible and Gowen 1961; Eicher and Beamer 1976). The Snell, Ames and Little dwarf mice are deficient for both GH and PRL (Beamer and Eicher 1976; Slabaugh et al. 1981). In one dwarf strain, little, a recessive mutation affects the GRF receptor such that somatotrope cells do not produce sufficient GH (Jansson et al. 1986). In the other lines the primary defects are unknown. Here we have genetically depleted the cells that produce GH and PRL and therefore understand the lesion that results in the observed dwarfism. Although not every somatotrope was ablated, it is clear that $\mathrm{GH}$ levels were lower than physiological levels required for the stimulation of normal growth. By crossing the 1982-2 dwarf mice with transgenic mouse lines carrying other genes involved in somatic growth, we hope to determine the actions of these genes on growth in the absence of endogenous $\mathrm{GH}$.

The general architecture of the pituitary in the 1982-2 line of mice appears normal, although the entire organ is smaller. Because GH synthesis commences after the morphogenesis of the pituitary is nearly complete, death of the somatotropes may not significantly influence the development of this organ. In contrast, depletion of pancreatic acinar cells from transgenic mice with elastaseDT-A results in a severe underrepresentation of duct and islet cells as well (Palmiter et al. 1988). In that model the elastase gene is first expressed at about fetal day 14, at a time when the pancreatic rudiment is still very small; presumably the death of the acinar cells affects the development of the other pancreatic cell types. Although we have not assayed the function of all the endocrine cell types in the pituitary, other endocrine cells are present in the adenohypophysis, and the phenotype of the mice does not suggest a deficiency in ACTH or TSH.

One of the goals of these experiments was to gain insights into the lineal relationships between somatotropes and lactotropes. In mice, GH expression precedes PRL synthesis by about 2 weeks (Slabaugh et al. 1982). This temporal relationship and the finding that in rats most of the initial PRL secreting cells also express GH suggested that PRL-synthesizing cells are derived from a GH-expressing progenitor (Hoeffler et al. 1985). If all PRL cells are derived from GH-expressing cells, then we would have expected to observe a depletion of both PRL and $\mathrm{GH}$ cells from transgenic mice expressing $\mathrm{rGH}$
DT-A. In the 1982-2 line we observe an average of about $10 \mathrm{GH}$-positive cells, per pituitary compared to a normal number of about 200,000 . However, there are several hundred PRL-positive cells, indicating that many of them were derived from cells that never synthesized $\mathrm{GH}$. Furthermore, the development of these PRL cells did not depend upon the presence of GH cells or their diffusible products. The presence of a few GH-positive cells probably reflects a rare loss or inability to activate the toxin gene. These GH-positive cells are occasionally present in small clusters, suggesting that they may be the progeny of a single cell that escaped activation of the transgene. This rare event may be due to gene deletion, mutation, or some epigenetic event such as DNA methylation.

Because there are always more PRL-positive cells than GH-cells in the 1982-2 line and the single dwarf founder female 159-7, there may be more than one lineage pathway for their development. One possibility is that a stem cell synthesizing neither GH nor PRL usually gives rise to cells that initially synthesize $\mathrm{GH}$ and then $\mathrm{GH}$ and PRL (Hoeffler et al. 1985). Cells synthesizing both hormones subsequently give rise to cells synthesizing PRL only. Occasionally the stem cell gives rise to cells capable of synthesizing only PRL. A summary of these lineal relationships is depicted in Figure 7. In this model there are two pathways for developing lactotropes. The major pathway would be ablated by rGH-DT-A expression, but the minor pathway would contribute the small number of PRL cells that appear in these mice. Such a system would produce a lactotrope subpopulation that

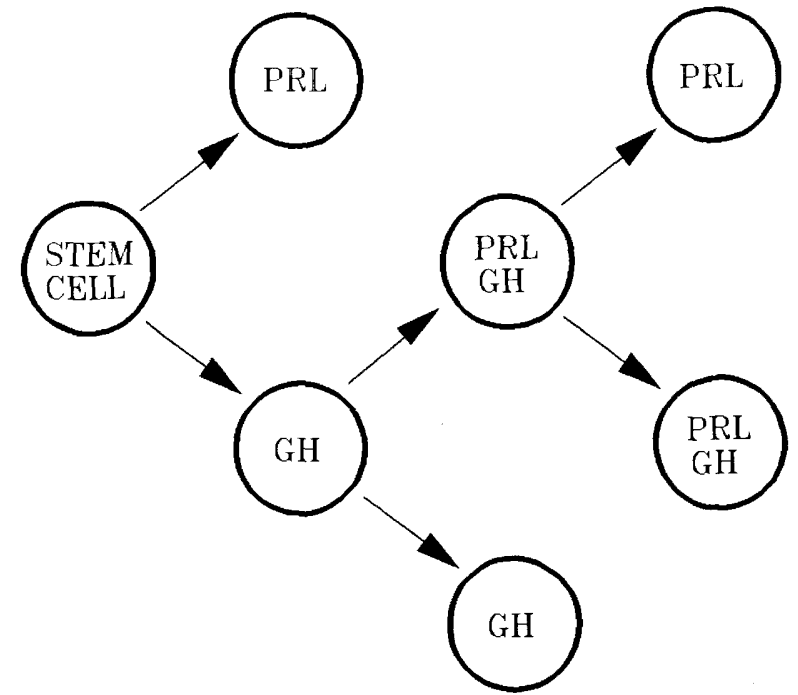

Figure 7. Diagram of model summarizing lineal relationships among progenitors of somatotropes and lactotropes in rodents. Biochemical and immunocytochemical data suggest that: $\mathrm{GH}$ positive, cells appear first, most of the early PRL-positive cells are also GH positive, and later PRL-positive cells appear (Slabaugh et al. 1982; Hoeffler et al. 1985). Data from the 1982-2 line support this pathway but indicate that a population of PRL-positive cells may arise directly from a non-GH-expressing stem cell. 
might possess unique physiological functions (Walker and Farquhar 1980; Frawley and Clark 1986; Boockfor et al. 1986; Boockfor and Frawley 1987). An alternative explanation for the greater abundance of PRL cells than GH-positive cells in the 1982-2 line is that expression of rGH-DT-A is delayed relative to endogenous GH synthesis; thus, some cells may have specialized in the direction of PRL synthesis, thereby removing signals for transgene activation.

We have demonstrated that the genetic ablation of specific cell types in transgenic mice can be a useful method for understanding cell lineage relationships and the role of particular cell types in morphogenesis. Finally, if that cell type produces a hormone one can generate a hormone-deficient animal model.

\section{Methods \\ Plasmid constructions}

For $\mathrm{rGH}-\mathrm{hGH}$, the BamHI site at +2 of the hGH gene /Seeburg 1982) was converted to XhoI with a synthetic linker, CCTCGAGG, that would regenerate the BamHI site. The rGH. flanking region (Barta et al. 1981) was joined via its natural $X$ hol site, located at +7 , to the hGH gene. To generate rGHDT-A, the 795-bp DT-A cassette (Palmiter et al. 1987), bounded by $B g l I I$ sites, was inserted into the $B a m H I$ site of $\mathrm{rGH}-\mathrm{hGH}$. The KpnI $(-310)$ to EcoRI fragment from both types of plasmids was isolated for microinjection. Transgenic mice were produced and identified as described previously (Brinster et al. $1985)$.

\section{Analysis of hGH mRNA levels}

Nucleic acids were purified from tissues by homogenization in SDS/Proteinase $\mathrm{K}$ followed by phenol/chloroform extraction and ethanol precipitation. hGH mRNA was quantitated by solution hybridization using an end-labeled oligonucleotide directed against hGH as described (Durnam and Palmiter 1983; Ornitz et al. 1985)

\section{Immunocytochemistry}

Pituitaries from wild-type and transgenic mice were dissected and placed in Carnoy's fixative for a minimum of 24-hr and then embedded in paraffin. Indirect immunofluorescent staining was performed on deparaffinized $5-\mu \mathrm{m}$ sections. All primary antisera were obtained from Dr. A.F. Parlow through the NIADDK (Bethesda, MD). To examine rGH-DT-A pituitaries, antiserum to $\mathrm{rGH}$ (monkey) for endogenous mouse GH visualization and mouse PRL (rabbit) were diluted $1: 20$ and $1: 5$, respectively, with PBS. The secondary antibodies, fluorescein isothiocyanate-conjugated goat anti-monkey immunoglobulin and rhodamine-conjugated goat anti-rabbit immunoglobulin (Cooper Biomedical-Cappel), were diluted 1:50 with PBS. To examine hGH and mPRL expression simultaneously in $\mathrm{rGH}-\mathrm{hGH}$ pituitaries, antiserum to human $\mathrm{GH}$ (rat) was diluted $1: 100$; the secondary antibody, fluorescein-conjugated goat anti-rat immunoglobulin was diluted $1: 50$. mPRL was visualized as above. To examine hGH and mGH expression simultaneously, antiserum to hGH (rabbit) was diluted 1:500; the secondary antibody, rhodamine-conjugated goat anti-rabbit immunoglobulin, was diluted $1: 50$. mGH was visualized as above. Experiments were performed to show that the antiserum to human GH did not recognize endogenous mouse GH in pituitary sections.

\section{Circulating hormone determinations}

Circulating GH concentrations were determined by double-antibody RIA against rat GH using materials supplied by the NIADDK (Bethesda, MD). GH values are reported in terms of the mouse GH reference preparation. The minimum detectable level of $\mathrm{GH}$ was $0.78 \mathrm{ng} / \mathrm{ml}$. Circulating IGF-I was measured by RIA as described (D'Ercole et al. 1980).

\section{Acknowledgments}

We thank our colleagues for critical review of the manuscript. We also thank A.F. Parlow (UCLA) for supplying the primary antibodies used for immunocytochemistry, Gloria Tannenbaum for serum GH determinations, Joe D'Ercole for IGF-I measurements, and Tom Downs for analysis of plasma human GRF. We also thank Mary Avarbock and Felicity Oram for technical assistance, also Glenda Froelick and Doreen Lucas for histology. We are grateful for the continuing interest of Ian Maxwell and the contributions of Bob Hammer. This work was supported in part by National Institutes of Health Grants HD09172 (R.D.P.) and HD19018 (R.L.B.).

\section{References}

Bancroft, F.C. 1981. GH cells: functional clonal lines of rat pituitary tumor cells. In Functionally differentiated cell lines, (ed. G. Sato), pp. 47-55. Alan R. Liss, New York.

Barta, A., R.I. Richards, J.D. Baxter, and J. Shine. 1981. Primary structure and evolution of the rat growth hormone gene. Proc. Natl. Acad. Sci. 78: 4867-4871.

Beamer W.G. and E.M. Eicher. 1976. Stimulation of growth in the little mouse. I. Endocrinol. 71: 37-45.

Bodner, M. and M. Karin. 1987. A pituitary-specific trans-acting factor can stimulate transcription from the growth hormone promoter in extracts of nonexpressing cells. Cell 50: 267275.

Boockfor, F.R. and L.S. Frawley. 1987. Functional variations among prolactin cells from different pituitary regions. Endocrinology 120: 874-879.

Boockfor, F.R., J.P. Hoeffler, and L.S. Frawley. 1986. Analysis by plaque assays of $\mathrm{GH}$ and prolactin release from individual cells in cultures of male pituitaries: Evidence for functional heterogeneity within rat mammotrope and somatotrope populations. Neuroendocrinology 42: 64-70.

Brinster, R.L., H.Y. Chen, M.E. Trumbauer, M.K. Yagle, and R.D. Palmiter. 1985. Factors affecting the efficiency of introducing foreign DNA into mice by microinjecting eggs. Proc. Natl. Acad. Sci. 82: 4438-4442.

Brinster, R.L., J.M. Allen, R.R. Behringer, R.E. Gelinas, and R.D. Palmiter. 1988. Introns increase transciptional efficiency in transgenic mice. Proc. Natl. Acad. Sci. 85: 836-840.

Cameron, R.A., B.R. Hough-Evans, R.J. Britten, and E.H. Davidson. 1987. Lineage and fate map of each blastomere of the eight-cell sea urchin embryo. Genes Dev. 1: 75-84.

Chubb, C. 1987. Sexual behavior and fertility of little mice. Biol. Reprod. 37: 564-569.

Dale, L. and J.M.W. Slack. 1987. Fate map for the 32-cell stage of Xenopus laevis. Development 99: 527-551.

D'Ercole, A.J., G.T. Applewhite, and L.E. Underwood. 1980. Evidence that somatomedin is synthesized by multiple tissues in the fetus. Dev. Biol. 75: 315-328. 
D'Ercole, A.J., A.D. Stiles, and L.E. Underwood. 1984. Tissue concentrations of somatomedin C: Further evidence for multiple sites of synthesis and paracrine or autocrine mechanisms of action. Proc. Natl. Acad. Sci. 81: 935-939.

Durnam, D.M. and R.D. Palmiter. 1983. A practical approach for qunatitating specific mRNAs by solution hybridization. Anal. Biochem. 131: 385-393.

Eden, S. 1979. Age- and sex-related differences in episodic growth hormone secretion in the rat. Endocrinology 105: $555-560$.

Eicher, E.M. and W.G. Beamer. 1976. Inherited ateliotic dwarfism in mice. /. Hered. 67: 87-91.

Frawley, L.S. and C.L. Clark. 1986. Ovine prolactin (PRL) and dopamine preferentially inhibit PRL release from the same subpopulation of rat mammotropes. Endocrinology 119: 1462-1466.

Frawley, L.S., F.R. Boockfor, and J.P Hoeffler. 1985. Identification by plaque assays of a pituitary cell type taht secretes both growth hormone and prolactin. Endocrinology 116: $734-737$.

Jansson, J., T.R. Downs, Beamer, W.G., and L.A. Frohman. 1986. Receptor-associated resistance to growth hormone-releasing factor in dwarf 'little' mice. Science 232: 511-512.

Hammer, R.E., Palmiter, R.D., and R.L. Brinster. 1984. Partial correction of murine hereditary disorder by germ-line incorporation of a new gene. Nature 311: 65-67.

Hammer, R.E., R.L. Brinster, M.G. Rosenfeld, R.M. Evans, and K.E. Mayo. 1985. Expression of human growth hormone-releasing factor in transgenic mice results in increased somatic growth. Nature 315: 413-416.

Hoeffler, J.P., F.R. Boockfor, and L.S. Frawley. 1985. Ontogeny of prolactin cells in neonatal rats: Initial prolactin secretors also release growth hormone. Endocrinology 117: 187-195.

Lawson, K.A. and R.A. Pederson. 1987. Cell fate, morphogenetic movement and population kinetics of embryonic endoderm at the time of germ layer formation in the mouse. Development 101: 627-652.

Lefevre, C., M. Imagawa, S. Dana, J. Grindlay, M. Bodner, and M. Karin. 1987. Tissue-specific expression of the human growth hormone gene is conferred in part by the binding of a specific trans-acting factor. EMBO I. 6: 971-981.

Mathews, L.S., G. Norstedt, and R.D. Palmiter. 1986. Regulation of insulin-like growth factor I gene expression by growth hormone. Proc. Natl. Acad. Sci. 83: 9342-9347.

Maxwell, I.H., F. Maxwell, and L.M. Glode. 1986. Regulated expression of a diphtheria toxin A-chain gene transfected into human cells: A possible strategy for inducing cancer cell suicide. Cancer Res. 46: 4660-4664.

Nelson, C., E.B. Crenshaw, III, R. Franco, S.A. Lira, V.R. Albert, R.M. Evans, and M.G. Rosenfeld. 1986. Discrete cis-active genomic sequences dictate the pituitary cell type-specific expression of rat prolactin and growth hormone genes. $\mathrm{Na}$ ture 322: 557-562.

Nishida, H. and N. Satoh. 1983. Cell lineage analysis in ascidian embryos by intracellular injection of a tracer enzyme. I. Up to the eight-cell stage. Dev. Biol. 99: 382-394.

- 1985. Cell lineage analysis in ascidian embryos by intracellular injection of a tracer enzyme. II. The sixteen-cell and thirty-two-cell stage. Dev. Biol. 110: 440-454.

Ornitz, D.M., R.D. Palmiter, R.E. Hammer, R.L. Brinster, G.H. Swift, and R.J. MacDonald. 1985. Specific expression of an elastase-human growth hormone fusion gene in pancreatic acinar cells of transgenic mice. Nature 313: 600-602.

Palmiter, R. D., R. L. Brinster, R. E. Hammer, M. E. Trumbauer, M. G. Rosenfeld, N. C. Birnberg, and R. M. Evans 1982. Dramatic growth of mice that develop from eggs microinjected with metallothionein-growth hormone fusion genes. Nature 300: 611-615.

Palmiter, R.D., G. Norstedt, R.E. Gelinas, R.E. Hammer, and R.L. Brinster. 1983. Metallothionein-human GH fusion genes stimulate growth of mice. Science 222: 809-814.

Palmiter, R.D., R.R. Behringer, C.J. Quaife, F. Maxwell, I.H. Maxwell, and R.L. Brinster. 1987. Cell lineage ablation in transgenic mice by cell-specific expression of a toxin gene. Cell 50: 435-443.

Roberts, C.T., Jr., A.L. Brown, D.E. Graham, S. Seelig, S. Berry, K.H. Gabbay, and M.M. Rechler. 1986. Growth hormone regulates the abundance of insulin-like growth factor I RNA in adult rat liver. J. Biol. Chem. 261: 10025-10029.

Sasaki, F. and M. Sano. 1982. Role of the ovary in the sezual differentiation of prolactin and growth hormone cells in the mouse adenohypophysis: A stereological morphometric study by electron microscopy. I. Endocrinol 93: 117-121.

Schaible, R., and J.W. Gowen. 1961. A new dwarf mouse. Genetics 46: 896.

Seeburg, P.H. 1982. The human growth hormone gene family: nucleotide sequences show recent divergence and predict a new polypeptide hormone. DNA 1: 239-249.

Slabaugh, M.B., M.E. Lieberman, J.J. Rutledge, and J. Gorski. 1981. Growth hormone and prolactin synthesis in normal and homozygous Snell and Ames dwarf mice. Endocrinology 109: 1040 - 1046.

Slabaugh, M.B., M.E. Lieberman, J.J. Rutledge, and J. Gorski. 1982. Ontogeny of growth hormone and prolactin gene expression in mice. Endocrinology 110: 1489-1497.

Snell, G.D. 1929. 'Dwarf' a new Mendelian recessive character of the house mouse. Proc. Natl. Acad. Sci. 15: 733-734.

Sulston, J. E., E. Schierenberg, J. G. White, and J. N. Thompson 1983. The embryonic cell lineage of the nematode Caenorhabditis elegans. Dev. Biol. 100: 64-119.

Technau, G.M. 1987. A single cell approach to problems of cell lineage and commitment during embryogenesis of Drosphila melanogaster. Development 100: 1-12.

Van Wyk, J.J. 1984. The soamtomedins: Biological actions and physiologic control mechanisms. In Hormonal proteins and peptides, (ed. C.H. Li), vol. 12, pp. 81-125. Academic Press, New York.

Walker, A.M. and M.G. Farquhar. 1980. Preferential release of newly synthesized prolactin granules is the result of functional heterogeneity among mammotrophs. Endocrinology 107: 1095-1104.

Walker, D.G., M.E. Simpson, C.W. Asling, and H.M. Evans. 1950. Growth and differentiation in the rat following hypophysectomy at 6 days of age. Anat. Record 106: 539-554.

West, B.L., D.F. Catanzaro, S.H. Mellon, P.A. Cattini, J.D. Baxter, and T.L. Reudelhuber. 1987. Interaction of a tissuespecific factor with an essential rat growth hormone gene promoter element. Mol. Cell. Biol. 7: 1193-1197. 


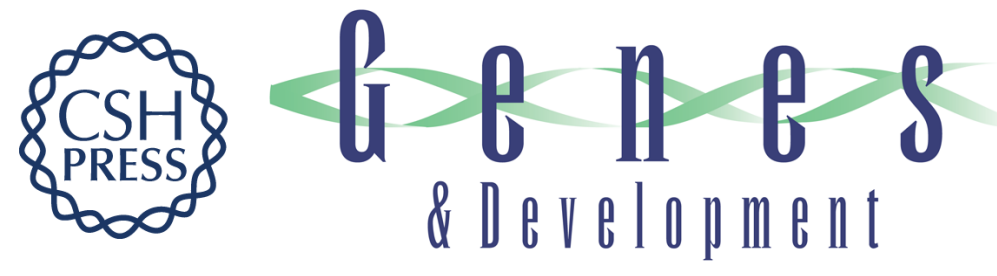

\section{Dwarf mice produced by genetic ablation of growth hormone-expressing cells.}

R R Behringer, L S Mathews, R D Palmiter, et al.

Genes Dev. 1988, 2:

Access the most recent version at doi:10.1101/gad.2.4.453

References This article cites 44 articles, 16 of which can be accessed free at:

http://genesdev.cshlp.org/content/2/4/453.full.html\#ref-list-1

License

Email Alerting Receive free email alerts when new articles cite this article - sign up in the box at the top Service right corner of the article or click here.

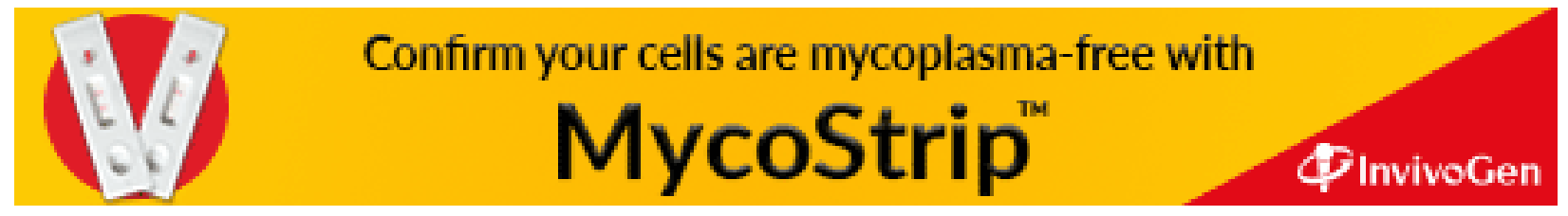

